\title{
FREQUÊNCIA ESCOLAR NA EDUCAÇÃO INFANTIL: PERCEPÇÕES DAS FAMÍLIAS E DOS PROFISSIONAIS DA EDUCAÇÃO ${ }^{1}$
}

\author{
Maria Beatriz Vasconcelos Silva (UFMG)* \\ https://orcid.org/0000-0002-4773-1981 \\ Lívia Fraga Vieira (UFMG)** \\ https://orcid.org/0000-0002-9036-0151
}

\section{RESUMO}

Em pesquisa realizada em 2016 e 2017, pretendeu-se conhecer os motivos, os fatores influenciadores e as justificativas da infrequência das crianças na educação infantil, na perspectiva das famílias e dos profissionais da educação no contexto de três Escolas Municipais de Educação Infantil da Secretaria de Educação de Belo Horizonte, MG, escolhidas conforme o Índice de Desenvolvimento Humano Municipal do bairro. Foram analisados os diários de classe das turmas e aplicados 233 questionários aos familiares, os quais também foram entrevistados juntamente com os profissionais da educação (diretoras, coordenadoras, docentes e técnica educacional). Constatou-se que o principal motivo da infrequência é o adoecimento da criança. Fatores impeditivos relacionados às condições de moradia, ao emprego, à constituição das famílias (chefiadas por mulheres, mães adolescentes) foram igualmente constatados, evidenciando que a infrequência escolar é maior entre crianças vivendo em situações de vulnerabilidade social.

Palavras-chave: Educação infantil. Frequência escolar. Vulnerabilidade social. Escolas municipais de educação infantil. Belo Horizonte.

\section{ABSTRACT}

\section{SCHOOL FREQUENCY IN EARLY CHILDHOOD EDUCATION: PERCEPTIONS OF FAMILIES AND EDUCATION PROFESSIONALS}

In a survey conducted in 2016 and 2017, it was intended to know the reasons, the influencing factors and the justifications for the infrequency of children in early childhood education, from the perspective of families and education professionals in the context of three Municipal Schools of Early Childhood Education. Education of Belo Horizonte / MG, chosen according to the Municipal Human Development Index of the neighborhood. The class diaries of the classes

1 Esta pesquisa foi submetida ao Comitê de Ética da Pesquisa da UFMG, sendo autorizada a sua execução.

* Mestre em Educação pela Universidade Federal de Minas Gerais (UFMG). Professora da Educação Básica da rede municipal de Belo Horizonte. E-mail: bia.ovsilva@hotmail.com

** Doutora em Educação pela Universidade de Paris 5, Sorbonne. Professora Associada da Faculdade de Educação da Universidade Federal de Minas Gerais (UFMG).E-mail: liviafraga59@gmail.com 
were analyzed and 233 questionnaires were applied to family members, which were also interviewed together with the education professionals (principals, coordinators, teachers and educational technique). It was found that the main reason for the infrequency is the child's illness. Impairing factors related to housing conditions, employment, and the constitution of families (headed by women, teenage mothers) were also found, showing that school attendance is higher among children living in socially vulnerable situations.

Keywords: Early childhood education. School attendance. Social vulnerability. Municipal schools of early childhood education. Belo Horizonte.

\section{RESUMEN}

\section{ASISTENCIA ESCOLAR EN LA EDUCACIÓN INFANTIL: PERCEPCIONES EM FAMILIAS Y PROFESIONALES DE LA EDUCACIÓN}

En una investigación realizada en 2016 y 2017, se pretendía conocer los motivos, factores influyentes y justificaciones de la poca asistencia de los niños en la educación de la primera infancia, desde la perspectiva de las familias y los profesionales de la educación en el contexto de tres Escuelas Municipales de Educación Infantil de la Secretaría de Educación de Belo Horizonte/ MG, elegida según el Índice de Desarrollo Humano Municipal del barrio. Se analizaron registros de clase de los grupos de estudiantes, se aplicaron 233 cuestionarios a miembros de la família, que tambien fueran entrevistados junto con los profesionales de la educación (directores, coordinadores, maestros y asistente educativa). Se encontró que la razón principal de la inasistencia es por enfermedad en los niños. También se encontraron factores perjudiciales relacionados con las condiciones de vivienda, el empleo, la constitución de las famílias (encabezadas por mujeres, madres adolescentes), lo que demuestra que la inasistencia a la escuela es mayor entre los niños que viven en situaciones socialmente vulnerables.

Palabras clave: Educación infantil. Asistencia escolar. Vulnerabilidad social. Escuelas municipales de educación infantil. Belo Horizonte.

\section{Introdução}

O princípio da igualdade de condições para o acesso e permanência na escola é um dos pilares para a garantia do direito à educação no Brasil e nas democracias. Desde 2009, o dever do Estado com a Educação se estabeleceu, entre outras garantias, com a ampliação da obrigatoriedade escolar para pessoas de quatro a dezessete anos, abarcando a frequência estudantil da pré-escola ao ensino médio. A Constituição Federal, promulgada em 1988, definiu a educação infantil em creches e pré-escolas, como direito de trabalhadores, rurais e urbanos, como direito das crianças e dever do Estado, atribuindo competência aos municípios pela sua oferta, no escopo do regime de colaboração dos entes federados.

Embora a oferta da educação infantil tenha aumentado exponencialmente nos últimos 20 anos, a análise das estatísticas demográficas e educacionais nos indicam inúmeras barreiras de acesso, decorrentes das desigualdades regionais e de renda, do pertencimento racial e da localização (rural/urbana). Mostra-se que as crianças mais pobres, cujas famílias perce- 
bem menos que meio salário mínimo mensal per capita, as negras e as que habitam áreas rurais e periféricas apresentam dificuldades de usufruírem do direito à educação infantil.

Assim, a educação infantil ainda não se configura como um direito que atinge a todas as crianças e famílias que manifestam por meios diversos a necessidade e o desejo de disporem de serviços públicos para a educação e o cuidado compartilhado de filhos pequenos.

Para as crianças que puderam acessar o direito à creche/pré-escola, como acontece a frequência à instituição de educação infantil? Essa foi a principal questão que motivou a pesquisa, cujos resultados apresentamos neste artigo. Buscou-se, nessa perspectiva, investigar as concepções das famílias e dos profissionais da educação sobre a frequência escolar das crianças matriculadas nas Escolas Municipais de Educação Infantil ${ }^{2}$ (EMEI) da Secretaria de Educação do município de Belo Horizonte. A investigação se justificou, em primeiro lugar, pela premissa de que o estudo da frequência escolar poderia apontar meios para compreendermos a concepção que os adultos envolvidos na rotina das crianças possuem sobre a escolarização na primeira infância. Além disso, foi motivada pela necessidade de conhecer as configurações que envolvem a frequência escolar das crianças pequenas frente à implementação da Lei no 12.796/2013 (BRASIL, 2013), que estendeu a faixa de matrícula obrigatória a partir da pré-escola.

As seguintes questões incitaram a pesquisa: Quais são os motivos de infrequência das crianças na Educação Infantil? Por que algumas se tornam infrequentes mesmo após terem encontrado dificuldade de conseguir vaga em instituição pública? Os motivos das faltas variam conforme a localização das instituições na cidade? Quais são as justificativas das famílias

2 Em alguns trechos de entrevistas poderá aparecer a sigla UMEI como referência às instituições públicas de atendimento à Educação Infantil em Belo Horizonte, tendo em vista que até o ano de 2018, tais locais eram designados como Unidades Municipais de Educação Infantil. A nomenclatura foi alterada pela Lei Municipal no 11.132/2018. para a infrequência escolar? Como os profissionais da educação percebem os aspectos que envolvem a frequência escolar das crianças na rotina da instituição?

A fim de respondermos tais perguntas optamos por realizar a pesquisa de campo na Região Norte do município de Belo Horizonte em três instituições, escolhidas conforme o Índice de Desenvolvimento Humano Municipal $(\mathrm{IDHM})^{3}$ do bairro em que estão localizadas, o que resultou na seleção apresentada a seguir.

EMEI A - Localizada em bairro com Alto IDHM, foi construída em uma área que iniciou seu processo de ocupação a partir da década de 1950, como opção de moradia para os trabalhadores que não tinham condições de morar no Centro da cidade. Apesar de pertencer à regional Norte, o bairro sofreu a influência da expansão da regional Venda Nova, que possui um importante centro comercial e de serviços, e da regional Pampulha, que desde sua construção atraiu moradores devido à modernização e à variedade de opções de lazer. Tais características, aliadas à abertura de importantes avenidas, fizeram com que o bairro fosse se "constituindo por casas e apartamentos com bons padrões de construção" (BELO HORIZONTE, 2011, p. 23).

EMEI B - Localizada em bairro com Médio IDHM. O bairro está localizado em uma área considerada distante do Centro da capital, anteriormente ocupada por sítios e fazendas. Essa área, para acompanhar o desenvolvimento urbano e acomodar a população crescente, foi dividida em lotes na década de 1940. Entretanto, situação recorrente na Regional Norte,

3 Em 2012, o Programa das Nações Unidas para o Desenvolvimento (PNUD Brasil), o Instituto de Pesquisa Econômica Aplicada (IPEA) e a Fundação João Pinheiro realizaram estudo visando adaptar a metodologia do Índice de Desenvolvimento Humano (IDH) Global para calcular o IDH Municipal (IDHM) dos 5.565 municípios brasileiros. Posterior ao IDHM dos municípios brasileiros, as três instituições empreenderam a tarefa de calcular o IDHM em nível intramunicipal das regiões metropolitanas do país - desta vez, para as Unidades de Desenvolvimento Humano (UDH). O IDHM brasileiro considera as mesmas três dimensões do IDH Global - longevidade, educação e renda. (PROGRAMA DAS NAÇÕES UNIDAS PARA O DESENVOLVIMENTO, 2013). 
a ocupação foi marcada pela falta de planejamento e auxílio do poder público (BELO HORIZONTE, 2011).

EMEI C - Localizada em bairro com Baixo IDHM. O bairro é considerado um aglomerado subnormal ${ }^{4}$ pelo Instituto Brasileiro de Geografia e Estatística (IBGE) e foi criado a partir da transferência de famílias de baixa renda oriundas de acampamentos que estavam localizados em outras partes da cidade. No mesmo território situa-se uma ocupação urbana, que teve início no ano de 2013, onde também habitam crianças que frequentam a EMEI C.

A região administrativa Norte sofreu e sofre processo de ocupação irregular e desordenada (BIZOTTO, 2015), apresentando bairros com boa infraestrutura, habitados por pessoas de maior poder aquisitivo e outros com estrutura mais precária, cujos moradores possuem menor renda (BELO HORIZONTE, 2011). Mesmo com a proximidade do ponto de vista geográfico dos bairros, as condições sociais e econômicas dos moradores não são equitativas no interior das regiões administrativas da cidade de Belo Horizonte, o que resulta em índices distintos de frequência escolar apresentados pelas crianças, como se mostrará a seguir.

Para apresentar uma análise dos indicadores que possibilitaram tal constatação, organizamos o artigo em três seções. A primeira apresenta uma breve fundamentação teórica e legal a respeito da temática. A segunda seção apresenta dados coletados nas fases da pesquisa, nas quais se utilizou a abordagem quantitativa, cujos procedimentos foram os seguintes:

1 - Leitura e análise dos diários de classe, nos quais se pretendeu levantar as seguintes infor-

4 O termo "Aglomerados Subnormais" surgiu em 1987, quando o IBGE iniciou uma reflexão a respeito das características de áreas conhecidas no Brasil por diversos nomes, como favela, comunidade, grotão, vila, mocambo, entre outros. A partir deste estudo, o conceito foi definido como sendo "o conjunto constituído por 51 ou mais unidades habitacionais caracterizadas por ausência de título de propriedade e pelo menos uma das características abaixo:irregularidade das vias de circulação e do tamanho e forma dos lotes e/ou-carência de serviços públicos essenciais (como coleta de lixo, rede de esgoto, rede de água, energia elétrica e iluminação pública) (INSTITUTO BRASILEIRO DE GEOGRAFIA E ESTATÍSTICA, 2012). mações: o número de crianças matriculadas nas unidades por faixa etária; as taxas de infrequência; em qual turno as crianças apresentam um maior número de faltas; em qual idade a frequência escolar é maior e menor; em que período do ano ocorre a maior incidência de faltas, e, também, se tais ocorrências são coincidentes nas três instituições.

2 - Elaboração, pré-teste, aplicação e análise dos questionários destinados às famílias, cujo objetivo foi o de investigar a relação entre os motivos de falta das crianças e as variáveis: local de moradia, cor, escolaridade, configuração familiar e gênero.

Na terceira seção são apresentados fragmentos das entrevistas realizadas com as famílias e profissionais da educação, o que se constituiu na terceira etapa da pesquisa. A realização das entrevistas visou complementar informações que permitissem um entendimento contextual dos dados quantitativos apurados nos diários de classe e nos questionários respondidos por familiares.

\section{Frequência escolar em creche e pré-escola: base legal}

O estudo da frequência escolar na educação infantil pode ser considerado uma novidade no campo de pesquisas em educação, tendo em vista a ausência de estudos que abordem esta temática na área. De acordo com a legislação vigente, a educação infantil é a primeira etapa da Educação Básica (BRASIL, 1996), e, a partir da implementação da Lei no $12.796 / 2013$ (BRASIL, 2013), passou a ser constituída por duas subetapas com regras distintas quanto à obrigatoriedade de matrícula e frequência escolar: creches, definidas como instituições que atendem crianças de zero a três anos, cujas matrículas devem ser efetivadas conforme opção da família; pré-escolas, instituições que atendem crianças de quatro a cinco anos, com matrícula compulsória por parte das famílias.

A despeito da novidade da legislação no que se refere à obrigatoriedade de matrícula das crianças na pré-escola por parte das 
famílias, cumpre salientar que o acesso à educação infantil é direito da criança desde o nascimento e deve ser garantido pelo Estado conforme registrado no artigo 208 da Constituição Federal de 1988 (BRASIL, 1988).

Entretanto, os dados oficiais apresentados pelo IBGE e pelo Censo Escolar demonstram que a oferta de vagas para atendimento às crianças pequenas no país ainda está distante do necessário para atender à demanda, sobretudo em relação à creche, conforme informações apresentadas no Quadro 1.

Quadro 1 -Taxa de escolarização das pessoas de 0 a 5 anos de idade, por grupos de idade na Educação Infantil, segundo Grandes Regiões, nos anos de 2017 e 2018 (\%)

\begin{tabular}{|l|c|c|c|c|c|c|}
\hline \multirow{2}{*}{ Brasil e Grandes Regiões } & \multicolumn{2}{|c|}{ De 0 a 1 ano } & \multicolumn{2}{c|}{2 a 3 anos } & \multicolumn{2}{c|}{4 e 5 anos } \\
\cline { 2 - 7 } & 2017 & 2018 & 2017 & 2018 & 2017 & 2018 \\
\hline Brasil & 12,8 & 12,5 & 51,1 & 53,8 & 91,7 & 92,4 \\
\hline Norte & 2,1 & 3,0 & 30,3 & 31,1 & 85 & 86,4 \\
\hline Nordeste & 4,4 & 4,6 & 52,0 & 54,2 & 94,8 & 95,4 \\
\hline Sudeste & 18,5 & 17,7 & 57,9 & 61,3 & 93 & 93,8 \\
\hline Sul & 25,0 & 21,6 & 53,8 & 55,2 & 88,9 & 90,0 \\
\hline Centro-Oeste & 10,3 & 11,4 & 39,5 & 43,0 & 86,9 & 86,3 \\
\hline
\end{tabular}

Fonte: Elaborado pelas autoras deste artigo com base em dados obtidos na Pesquisa Nacional por Amostra de Domicílios Contínua. Educação 2018 (INSTITUTO BRASILEIRO DE GEOGRAFIA E ESTATÍSTICA, 2019).

Nesse cenário, a determinação legal por obrigatoriedade de matrícula na pré-escola pode ser entendida como um meio para que os municípios, responsáveis pela manutenção e desenvolvimento da educação infantil, conforme o texto constitucional de 1988 (BRASIL, 1988), sejam pressionados a ampliar a quantidade de vagas.

De acordo com Monteiro (2003), o direito à educação deve ser entendido como um "meta direito" porque dele dependem "a capacidade de exercício dos direitos de cada um, assim como a consciência do dever de respeitar os direitos dos outros". (MONTEIRO, 2003, p. 764). Ainda segundo esse autor, a educação obrigatória e gratuita acontece na maior parte dos países está associada ao entendimento de que deve existir a garantia por parte do Estado de uma escolarização básica, devido à sua importância para o desenvolvimento humano e social.

Todavia, alguns especialistas, analisando o contexto brasileiro, chamam a atenção para o risco de que, em contrapartida, a obrigatorie- dade de matrícula na pré-escola desestimule o investimento na creche, perpetuando e agravando o déficit de vagas para a faixa etária de 0 a 3 anos (CAMPOS, 2010; DIDONET, 2009; VIEIRA, 2011).

Além da obrigatoriedade de matrícula, a Lei no 12.796/2013 (BRASIL, 2013) instituiu a necessidade de que as crianças matriculadas na pré-escola cumpram um índice de frequência escolar que contemple $60 \%$ do total anual de 200 dias letivos. Diz a Lei, também, que o acompanhamento e controle desta frequência deve ser feito pelas instituições. Há que se ressaltar aqui o caráter de compartilhamento da responsabilidade pela educação das crianças pequenas entre instituições e famílias (BRASIL, 1996) e a dependência que elas possuem frente aos adultos para terem seus direitos efetivados de usufruir o acesso, o que nos leva a inferir que o estudo da frequência escolar e da forma como ocorre seu acompanhamento pode oferecer subsídios para compreendermos como os adultos entendem a escolarização das crianças pequenas e concorrem para a sua efetivação. 
Diários de classe e questionários: o que nos informam sobre a frequência escolar nas EMEI

A análise dos Diários de Classe ${ }^{5}$ possibilitou calcular a quantidade total de faltas de cada criança e as médias por turma, por idade e por turno. Foram analisados os diários de todas as turmas que compunham as EMEI durante o ano de 2016, ${ }^{6}$ tendo sido 22 turmas na EMEI A, 19 turmas na EMEI B e 19 turmas na EMEI C.

Como resultado desse mapeamento, o dado que sobressai em primeiro lugar (Tabela 1) refere-se à média superior de faltas encontradas na EMEI $C$, aquela que se encontra localizada no bairro com o IDHM mais baixo.

Tabela 1 - Média de faltas nos turnos de atendimento integral, parcial - manhã e parcial - tarde, segundo EMEI, Belo Horizonte, 2016

\begin{tabular}{lccc}
\hline Turnos de atendimento & EMEI C & EMEI B & EMEI A \\
\hline Integral & 54 & 26 & 42 \\
Parcial manhã & 42 & 38 & 37 \\
Parcial tarde & 34 & 32 & 28 \\
\hline
\end{tabular}

Fonte: Elaborada pelas autoras deste artigo com base em dados da pesquisa (SILVA, 2018).

Importa registrar que esse dado possibilitou a refutação de uma hipótese inicial apresentada pelas autoras de que os índices de frequência escolar seriam maiores na EMEI C por atender a população mais vulnerável. Todavia, como será discutido adiante, os resultados demonstraram que as famílias atendidas por esta EMEI enfrentam situações cotidianas inerentes à condição social e econômica que dificultam uma presença efetiva e continuada das crianças.
É possível perceber também pelos resultados apresentados na Tabela 1 que existiu uma maior média de faltas entre as crianças matriculadas no turno Integral nas EMEI C e A e uma média superior de faltas no turno da manhã nas três EMEI. Chama a atenção, novamente, a quantidade superior de faltas na EMEI C, exceto para a idade de dois a três anos, em que a média maior de faltas se encontra na EMEI A.

Tabela 2 - Média de faltas por idade, nos turnos de atendimento parcial - manhã e parcial - tarde, segundo EMEI, Belo Horizonte, 2017

\begin{tabular}{l|ccccc|cc}
\hline \multicolumn{1}{c|}{ Idades } & \multicolumn{2}{|c|}{ EMEI C } & \multicolumn{2}{c|}{ EMEI B } & \multicolumn{2}{c}{ EMEI A } \\
& MANHÃ & TARDE & MANHÃ & TARDE & MANHÃ & TARDE \\
\hline 3 anos & 36 & 35 & 41 & 25 & 36 & 23 \\
4 anos & 47 & 32 & 35 & 35 & 34 & 31 \\
5 anos & 36 & 35 & 38 & 27 & 42 & 27 \\
\hline
\end{tabular}

Fonte: Elaborada pelas autoras deste artigo com base em dados da pesquisa (SILVA, 2018).

5 O Diário de Classe é um instrumento utilizado para registrar diversos aspectos relacionados à organização da rotina de cada turma, tais como: os nomes das crianças; dados pessoais; data de matrícula; quantidade de dias letivos mensais; data de desligamento da criança, quando for o caso; chamada diária das crianças, a qual é feita pela professora que apura ausentes e presentes; a proposta de trabalho anual para a turma, considerando a idade das crianças; planejamento mensal de atividades; dados pessoais das crianças; datas de ingresso e transferência e relatório de desenvolvimento individual (SILVA, 2018).
Quando consideramos apenas os turnos Parcial Manhã e Parcial Tarde (Tabela 2), podemos constatar que, em todas as EMEI e para todas as idades, a média de faltas tende a ser

6 Embora a análise dos diários de classe tenha sido realizada durante os meses de junho a agosto de 2017, foi necessário tomar os índices de frequência do ano anterior, tendo em vista que importava o resultado total anual de cada turma. 
superior no turno da manhã. A idade em que a média alcançou o maior índice foi a de quatro anos na EMEI C, turno da manhã (47 faltas por criança), e a idade em que alcançou o menor valor foi a de três anos na EMEI A, turno da tarde (23 faltas por criança).

Os resultados apresentaram a média geral de faltas, ou seja, são o quociente da divisão entre a quantidade de faltas anuais pelo total de crianças matriculadas.

Ressalte-se que, durante a análise dos diários de classe, houve um dado que apresentou relevância considerável e que merece ser citado. Trata-se da quantidade de crianças que apresentam uma quantidade superior à média geral, não conseguindo alcançar o índice de 60\% de frequência estipulado pela legislação para a pré-escola (BRASIL, 2013), ou seja, apresentaram mais de 80 faltas anuais. A Tabela 3 apresenta tais números e é possível perceber que na EMEI $C$ também foi superior a quantidade de crianças nessa situação.

Tabela 3 - Quantidade de crianças com mais de $60 \%$ de faltas anuais, em 2016, segundo EMEI

\begin{tabular}{c|c}
\hline EMEI & Quantidade de crianças \\
\hline EMEI C & 45 \\
EMEI B & 16 \\
EMEI A & 14 \\
\hline
\end{tabular}

Fonte: Elaborada pelas autoras deste artigo com base em dados da pesquisa (SILVA, 2018).

Os resultados encontrados nos Diários de Classe serviram para realizar um mapeamento inicial da frequência escolar e suscitaram diversos questionamentos, dentre os quais o mais potente refere-se à necessidade de se compreender os motivos da ocorrência de uma maior quantidade de faltas entre as crianças da EMEI C. Para tanto, a aplicação dos questionários ${ }^{7}$ por meio de contato pessoal com os

7 Os questionários foram aplicados para os familiares das três instituições pesquisadas entre os meses de novembro e dezembro de 2017. Foram abordadas as pessoas que levavam e buscavam as crianças durante a entrada e saída, nos horários da manhã - às 07 e às $11 \mathrm{~h} 30$ - e tarde - às $13 \mathrm{~h}$ e às $17 \mathrm{~h} 30$ - tendo sido realizada uma visita em cada entrevistados foi essencial por que, a despeito de ser um instrumento de coleta de dados quantitativos, proporcionou uma aproximação corpo a corpo com as famílias e, consequentemente, uma maior compreensão das tarefas cotidianas que vivenciam, dentre as quais as que se referem à dinâmica necessária para garantir a presença da criança na instituição dia após dia.

Não foi possível alcançar com os questionários a totalidade do público atendido nas três instituições, pois optamos pela abordagem pessoal e mais próxima, com o intuito de tentar minimizar algumas limitações do uso deste instrumento, conforme apresentadas por Gil (2008, p. 122). Dentre os prováveis entraves, tentamos agir de tal forma que fosse possível: possibilitar o preenchimento até mesmo pelas pessoas que não sabiam ler e escrever; auxiliar as pessoas que porventura não compreendessem as questões; ter consciência das circunstâncias em que os questionários foram respondidos e assegurar que a maioria das pessoas devolvesse o instrumento preenchido de forma completa.

Contudo, é possível afirmar que alguns impedimentos para que um maior número de questionários fosse preenchido foram ocasionados pela organização da rotina dos familiares e da própria instituição, tendo em vista que, conforme notas registradas no caderno de campo, muitas pessoas não puderam responder sob a alegação de estarem atrasadas para o trabalho ou para buscar crianças em outras instituições, ou, ainda, para preparar refeições e/ou outros afazeres domésticos. Além disso, era comum ocorrer a dificuldade do preenchimento por familiares que estavam carregando ao colo as crianças pequenas.

Diante de tais justificativas, e da observação de alguns comportamentos durante a entrada e saída dos turnos, pode-se inferir que a dinâmi-

\footnotetext{
horário, totalizando doze oportunidades de aplicação. Dessa maneira, foi possível alcançar familiares de crianças dos dois turnos parciais e do turno integral em cada EMEI, totalizando o preenchimento de 75 questionários na EMEI A, 81 na EMEI B e 77 na EMEI C.
} 
ca de organização dos horários de entrada e saída dos turnos é marcada pela impessoalidade, tendo em vista que, nesses momentos, parece não haver espaço para maiores interações, pois os familiares, em sua maioria, demonstraram a necessidade de levar e buscar as crianças de forma rápida para dar conta de outras tarefas.

Para a análise dos questionários foi realizada uma tabulação cruzada, utilizando o software SPSS. De acordo com Gil (2008, p. 159), este tipo de tabulação "consiste na contagem das frequências que ocorrem juntamente em dois ou mais conjuntos de categorias", tendo sido os resultados organizados em tabelas. Nesse sentido, as respostas aos questionários possibilitaram conhecer o perfil social da população atendida por cada instituição segundo as variáveis: Cor (Tabela 4), Escolaridade (Tabela 5), Composição familiar (Tabela 6) e Sexo do respondente (Tabela 7 ).

Tabela 4 - Cor do respondente por EMEI (\%)

\begin{tabular}{lccccc}
\hline EMEI & Branca & Preta & Parda & Amarela & Indígena \\
\hline EMEI A & 23,9 & 21,7 & 47,8 & 4,3 & 2,2 \\
EMEI B & 41,3 & 15,9 & 41,3 & 1,6 & 0,0 \\
EMEI C & 14,3 & 20,0 & 60,0 & 2,9 & 2,9 \\
TOTAL & 29,2 & 18,8 & 47,9 & 2,8 & 1,4 \\
\hline
\end{tabular}

Fonte: Elaborada pelas autoras deste artigo com base em dados da pesquisa (SILVA, 2018).

Os índices apresentados na Tabela 4 referem-se à variável Cor, a qual, seguindo o formato adotado pelo IBGE, foi definida por autodeclaração dos respondentes ao questionário. Os resultados demonstram uma predominância da cor parda nas três EMEI, aspecto que tem sido tendência no país, pois, conforme dados da PNAD Contínua de 2016, entre os anos de 2012 e 2016, o percentual de autodeclarados brancos caiu de $46,6 \%$ para $44,2 \%$, enquanto o índice de pardos aumentou de $45,3 \%$ para $46,7 \%$ e o de pretos, de $7,4 \%$ para 8,2\% (INTITUTO BRASILEIRO DE GEOGRAFIA E ESTATÍSTICA, 2017).

De acordo com Gomes (2011, p. 110) os dados demográficos referentes à cor são passíveis "de diferentes interpretações econômicas, políticas e sociológicas". Conforme essa autora, a interpretação defendida pelo Movimento Negro é a de que o conjunto da população negra no Brasil seja definido pela incorporação das categorias raciais "preto" e "pardo". Nesse sentido, podemos admitir que a maior parte dos familiares respondentes nas três instituições está no conjunto da população negra.

Um aspecto que chama atenção é o número superior de negros na EMEI C em relação às demais, tendo em vista que, nessa instituição, tal categoria abarca $80 \%$ dos casos $(20,0 \%$ preta e $60 \%$ parda). Esse resultado confirma a constatação de Motta (2017), o qual, ao realizar um estudo sobre a desigualdade socioespacial que atinge a população dos aglomerados subnormais de Belo Horizonte, pode verificar que

[...] cerca de 74\% dos moradores de favelas em Belo Horizonte são negros (pretos ou pardos) e estudos indicam que há ainda um diferencial de renda provindo de um mercado de trabalho segmentado e discriminatório contra esse grupo racial, principalmente do sexo feminino. (MOTTA, 2017, p. 11).

Na Tabela 5, sobre a escolaridade dos respondentes, os índices demonstram uma diferença significativa de resultados, reforçando o fato de existir uma distância social entre as três UMEIs, tendo em vista que a escolaridade é um dos fatores que reforçam o quadro de vulnerabilidade social de uma população, que "de forma indissociável relaciona-se com as dimensões econômicas e sociais" (XIMENES, 2010). Na EMEI A, o maior percentual encontra-se na opção Ensino Superior Completo. Na EMEI B, a maior parte dos respondentes assinalou ter Ensino Médio Completo e houve, também, um 
quantitativo considerável de concluintes do Ensino Superior. Quanto à EMEI C, os resultados indicam apenas 2,5\% de concluintes do Ensino Superior, enquanto a quantidade de pessoas com Ensino Fundamental Incompleto é mais que duas vezes o percentual da EMEI B. Na EMEI C, assim como na EMEI B, a maioria dos respondentes assinalou ter concluído o Ensino Médio.

Tabela 5 - Escolaridade do respondente, por EMEI (\%)

\begin{tabular}{cccccc}
\hline EMEI & $\begin{array}{c}\text { Fundamental } \\
\text { incompleto }\end{array}$ & $\begin{array}{c}\text { Fundamental } \\
\text { completo }\end{array}$ & $\begin{array}{c}\text { Ensino Médio } \\
\text { Incompleto }\end{array}$ & $\begin{array}{c}\text { Ensino Médio } \\
\text { Completo }\end{array}$ & $\begin{array}{c}\text { Ensino Superior } \\
\text { Completo }\end{array}$ \\
\hline EMEI A & 0,0 & 6,5 & 26,1 & 26,1 & 41,3 \\
EMEI B & 9,4 & 10,9 & 7,8 & 40,6 & 31,3 \\
EMEI C & 20,0 & 17,1 & 19,5 & 40,9 & 2,5 \\
TOTAL & 9,0 & 11,0 & 16,6 & 36,6 & 26,9 \\
\hline
\end{tabular}

Fonte: Elaborada pelas autoras deste artigo com base em dados da pesquisa (SILVA, 2018).

Em relação à Composição Familiar, percebemos com os dados registrados na Tabela 6 que prevalece, nas três UMEIs, o tipo nuclear (SZYMANSKY, 2002), tendo em vista que a maioria dos respondentes assinalou que a criança mora com a mãe e o pai e com mãe, pai e irmãos. É possível observar também que tal configuração está mais presente na EMEI A (78,3\%), seguida da EMEI B (70,3\%) e da EMEI C (51,4\%).

Quando observamos as composições familiares monoparentais, percebemos que os maiores índices se referem aos casos de famílias chefiadas por mulheres nas três UMEIs, com um número consideravelmente superior na EMEI C, pois, somados os índices de respostas aos itens "somente com a mãe" e "mãe e irmãos", temos o total de 40\% nesta EMEI. Na EMEI B este percentual chega a 15,6\%, e na EMEI A atinge 8,7\%. Em relação às famílias monoparentais masculinas, somados os resultados dos itens somente com o pai e pai e irmãos, temos 2,9\% na EMEI C, 4,7\% na EMEI $B$ e um resultado nulo na EMEI A. A ocorrência da supremacia de famílias monoparentais femininas ocorre em todo o país, tendo em vista que, de acordo com IBGE, entre os anos 2000 e 2010 , tal composição passou de $15,3 \%$ para $16,2 \%$, enquanto as masculinas se mantiveram nos mesmos patamares de $1,9 \%$ para $2,4 \%$. (INSTITUTO BRASILEIRO DE GEOGRAFIA E ESTATÍSTICA, 2012).

É necessário considerar que as famílias monoparentais femininas se encontram em situação de maior vulnerabilidade. De acordo com Babiuk (2015, p. 2), "as famílias monoparentais de mães sozinhas com filhos são mais vulneráveis no plano econômico, no provimento de víveres e nos cuidados prestados aos filhos". Ainda de acordo com essa autora, as situações de vulnerabilidade são agravadas para esse tipo de família devido às múltiplas jornadas exercidas pelas mulheres ligadas ao sustento emocional e econômico das famílias.

Tabela 6 - Composição familiar - pessoas que moram com a criança (\%), por EMEI

\begin{tabular}{lccccccc}
\hline & $\begin{array}{c}\text { Somente } \\
\text { mãe }\end{array}$ & $\begin{array}{c}\text { Mãe e } \\
\text { irmãos }\end{array}$ & $\begin{array}{c}\text { Somente } \\
\text { o pai }\end{array}$ & $\begin{array}{c}\text { Pai e } \\
\text { irmãos }\end{array}$ & Mãe e pai & $\begin{array}{c}\text { Mãe, pai e } \\
\text { irmãos }\end{array}$ & $\begin{array}{c}\text { Outros } \\
\text { parentes }\end{array}$ \\
EMEI A & 6,5 & 2,2 & 0,0 & 0,0 & 58,7 & 19,6 & 13,0 \\
EMEI B & 10,9 & 4,7 & 0,0 & 4,7 & 29,7 & 40,6 & 7,8 \\
EMEI C & 5,7 & 34,3 & 2,9 & 0,0 & 25,7 & 25,7 & 5,7 \\
TOTAL & 8,3 & 11,0 & 1,4 & 2,1 & 37,9 & 30,3 & 9,0 \\
\hline
\end{tabular}

Fonte: Elaborada pelas autoras deste artigo com base em dados da pesquisa (SILVA, 2018). 
A Tabela 7 apresenta a distribuição dos respondentes por sexo e os resultados mostram a predominância das mulheres nas três EMEI, especialmente na EMEI C $(91,4 \%)$. Assim, verifica-se que as mulheres são responsabilizadas pelas tarefas de buscar e levar as crianças às instituições cotidianamente.

Tabela 7 - Sexo do respondente (\%), por EMEI

\begin{tabular}{ccc}
\hline & Masculino & Feminino \\
\hline UMEI A & 26,1 & 73,9 \\
UMEI B & 33,3 & 66,7 \\
UMEI C & 8,6 & 91,4 \\
TOTAL & 25,0 & 75,0 \\
\hline
\end{tabular}

Fonte: Elaborada pelas autoras deste artigo com base em dados da pesquisa (SILVA, 2018).

As informações sobre a caracterização dos respondentes relativas às variáveis mencionadas (cor, escolaridade, sexo, arranjo familiar) mostraram que a maioria é de mulheres, predominantemente negras, que apresentam baixa escolaridade e se responsabilizam pelo cuidado das crianças e pela tarefa cotidiana de buscá-las e levá-las para a EMEI. Especialmente na EMEI C, essas características reforçam o quadro de vulnerabilidade da população atendida. Considerando que o estudo dos diários de classe apontou índices mais baixos de frequência escolar nessa instituição, a análise das variáveis demonstrou que para a população mais vulnerável existem fatores que potencializam as dificuldades de acesso à educação, incidindo também sobre as possibilidades de permanência e frequência efetiva das crianças. Tal constatação fica mais patente quando são analisados os motivos das faltas apontados pelas famílias, conforme será visto a seguir.

Para compor o quadro que apresenta os motivos de falta das crianças foi solicitado aos respondentes que assinalassem sim ou não para cada provável situação que pudesse interferir na frequência das crianças às instituições. Os resultados foram organizados na Tabela $8 \mathrm{e}$ enumerados em ordem decrescente, ou seja, os motivos que mais receberam respostas positivas aparecem nas primeiras posições.

Tabela 8 -Motivos de faltas das crianças por EMEI (\%)

\begin{tabular}{|lrrrrrrr|}
\hline & \multicolumn{2}{c}{ EMEI A } & \multicolumn{2}{c}{ EMEI B } & \multicolumn{2}{c|}{ EMEI C } \\
& SIM & NÃ0 & SIM & NÃ0 & SIM & NÃ 0 \\
\hline 1 - Adoecimento da criança & 80,4 & 19,6 & 68,8 & 31,3 & 57,1 & 42,9 \\
\hline 2 - Tratamentos médicos & 54,3 & 45,7 & 40,6 & 59,4 & 28,6 & 71,4 \\
\hline $\begin{array}{l}\text { 3 - Condições climáticas (se está frio, } \\
\text { se está chovendo etc.) }\end{array}$ & 32,6 & 67,4 & 15,6 & 84,4 & 45,7 & 54,3 \\
\hline $\begin{array}{l}\text { 4 - Atraso em relação aos horários } \\
\text { da EMEI }\end{array}$ & 13,0 & 87,0 & 14,1 & 85,9 & 34,3 & 65,7 \\
\hline $\begin{array}{l}\text { 5 - Dificuldade de chegar à EMEI } \\
\text { por falta de acessibilidade (ruas com } \\
\text { buracos, barro, poeira, por exemplo) }\end{array}$ & 0,0 & 100,0 & 1,6 & 98,4 & 25,7 & 74,3 \\
\hline $\begin{array}{l}\text { 6 - Acompanhamento especializado } \\
\text { terapeuta ocupacional, psicólogo, } \\
\text { fonoaudiólogo etc.) }\end{array}$ & 13,0 & 87,0 & 15,6 & 84,4 & 17,1 & 82,9 \\
\hline $\begin{array}{l}\text { 7 - Adoecimento dos pais e/ou } \\
\text { responsáveis. }\end{array}$ & 13,0 & 87,0 & 21,9 & 78,1 & 17,1 & 82,9 \\
\hline $\begin{array}{l}\text { 8 - Por falta de pessoas que façam } \\
\text { o traslado da criança. }\end{array}$ & 13,0 & 87,0 & 17,2 & 82,8 & 14,3 & 85,7 \\
\hline
\end{tabular}




\begin{tabular}{|lrrrrrr|}
\hline $\begin{array}{l}9 \text { - Incompatibilidade de horários em } \\
\text { relação ao trabalho dos pais }\end{array}$ & 17,4 & 82,6 & 9,4 & 90,6 & 14,3 & 85,7 \\
\hline $\begin{array}{l}10 \text { - Dificuldade de meio de transporte } \\
\text { para levar a criança. }\end{array}$ & 13,0 & 87,0 & 4,7 & 95,3 & 5,7 & 94,3 \\
\hline $\begin{array}{l}11 \text { - Distância entre a residência da } \\
\text { criança e a EMEI }\end{array}$ & 6,5 & 93,5 & 9,4 & 90,6 & 5,7 & 94,3 \\
\hline $\begin{array}{l}12 \text { - Dificuldade de adaptação da } \\
\text { criança à EMEI. }\end{array}$ & 2,2 & 97,8 & 9,4 & 90,6 & 5,7 & 94,3 \\
\hline $\begin{array}{l}13 \text { - Por causa do turno em que está } \\
\text { matriculada. }\end{array}$ & 2,2 & 97,8 & 7,8 & 92,2 & 2,9 & 97,1 \\
\hline
\end{tabular}

Fonte: Elaborada pelas autoras deste artigo com base em dados da pesquisa (SILVA, 2018).

Podemos observar que o adoecimento da criança foi apontado pelos respondentes como principal fator que provoca a infrequência escolar, seguido do motivo tratamentos médicos. Tais resultados estão relacionados à condição de vulnerabilidade inerente à saúde das crianças pequenas. 0 tratamento desta temática foi identificado em estudos da área da saúde, tais como Amorim e Rossetti-Ferreira (1999), Maranhão (2008), Rapoport e Piccinini (2001) e Pedraza, Queiroz e Sales (2014).

Um fator que chama a atenção é que o cruzamento das variáveis "idade da criança" e "adoecimento da criança" demonstrou que este motivo foi apontado com mais frequência pelos respondentes responsáveis pelas crianças menores, conforme pode ser conferido na Tabela 9.

Tabela 9 Motivo de falta por adoecimento, de acordo com a idade da criança (\%)

\begin{tabular}{ccc}
\hline Idade da criança & \multicolumn{2}{c}{$\begin{array}{c}\text { Motivo de falta da criança: } \\
\text { Adoecimento }\end{array}$} \\
\hline & Sim & Não \\
1 ano & 81,8 & 18,2 \\
2 anos & 93,3 & 6,7 \\
3 anos & 87,5 & 12,5 \\
4 anos & 57,1 & 42,9 \\
5 anos & 60,5 & 39,5 \\
6 anos & 45,5 & 54,5 \\
\hline
\end{tabular}

Fonte: Elaborada pelas autoras deste artigo com base em dados da pesquisa (SILVA, 2018).
Observa-se que, embora ainda seja indicado como motivo de falta, o adoecimento tende a diminuir conforme a idade da criança avança. Esse dado reitera os resultados encontrados na análise dos diários de classe, os quais indicaram um maior número de faltas para as crianças que frequentam a creche.

0 terceiro motivo a receber mais respostas positivas foi o relacionado às condições climáticas. Interessante observar que o índice foi maior na EMEI $\mathrm{C}$, a que atende famílias residentes na ocupação, as quais encontram dificuldades de acesso por residirem em local com infraestrutura ainda precária. Durante a aplicação dos questionários, as pessoas nessa EMEI justificavam a opção afirmativa para esse motivo, relatando que as ruas ficam com muito barro em períodos chuvosos, ou que os barracões são atingidos pela chuva, molhando as mochilas, material e roupas das crianças, pois as paredes não recebem reboco.

Além disso, em períodos com clima mais seco, as crianças adoecem com mais frequência, vítimas, em sua maioria, de doenças infecciosas respiratórias, conforme Amorim e RossettiFerreira (1999).

O motivo "Atraso em relação aos horários da EMEI" também demonstrou ser mais significativo para os respondentes da EMEI C.

A análise do quinto motivo, que consiste na dificuldade de chegar à EMEI por falta 
de acessibilidade, possibilita reforçar a afirmação que já fora aqui apresentada a qual consiste na constatação de que a população residente na área mais vulnerável sofre com questões ligadas à infraestrutura urbana causadas pela falta de planejamento e crescimento desordenado. Nesse item, chama atenção o fato de que $25 \%$ dos respondentes da EMEI C indicaram enfrentar tais impedimentos, enquanto na EMEI B tal índice fica em apenas $1,6 \%$ e chega a ser nulo na EMEI A. Outro motivo relacionado à saúde aparece como bastante significativo, especialmente na EMEI $C$, e refere-se às faltas causadas pela necessidade de acompanhamento especializado (Motivo 7). Nas justificativas encontradas nos Diários de Classe foi possível perceber que as crianças que fazem esse tipo de acompanhamento geralmente apresentam um dia determinado de falta de forma periódica, podendo ser semanalmente, quinzenalmente ou, ainda, mensalmente.

Os motivos 7, 8 e 9, os quais constituem, respectivamente, "Adoecimento dos pais e/ou responsáveis", "Por falta de pessoas que façam o traslado da criança" e "Incompatibilidade de horários em relação ao trabalho dos pais", apresentaram resultados aproximados nas três instituições e confirmam que a frequência escolar das crianças na Educação Infantil depende da organização da vida familiar e da disponibilidade de adultos que se responsabilizem por sua efetivação.

E, por fim, dentre os motivos apontados, os que demonstraram menor relevância no que se refere à influência para as faltas das crianças nas três instituições foram "Dificuldade de meio de transporte para levar a criança", "Distância entre a residência da criança e a EMEI", "Dificuldade de adaptação da criança à EMEI" e "Por causa do turno em que está matriculada". Possivelmente, tais motivos não se mostraram tão impactantes por causa da proximidade entre as residências das crianças e as instituições.

\section{Frequência escolar: o que pensam as famílias e os profissionais da educação}

Os sujeitos que concederam entrevistas foram divididos em dois grupos. Os integrantes do grupo de familiares foram selecionados conforme os resultados da análise dos diários de classe, tendo como critério o total de faltas anuais das crianças durante o ano de 2016. Foram escolhidas em cada EMEI duas famílias de crianças matriculadas na creche e duas famílias de crianças matriculadas na pré-escola, tendo sido uma frequente ${ }^{8}$ e outra infrequente em cada segmento, totalizando doze entrevistas, nas três EMEI. Quanto ao grupo dos profissionais da educação, foram entrevistados os seguintes sujeitos: Vice-diretoras, Coordenadoras Pedagógicas, Professoras e Auxiliares de Secretaria. Foi realizada também uma entrevista no âmbito da Secretaria Municipal de Educação (SMED), mais especificamente na Gerência de Coordenação da Educação Infantil (GECEDI).

O quadro abaixo sintetiza tais informações e apresenta as siglas que serão utilizadas para identificar os sujeitos ao longo do texto.

8 A título de definição de critério de seleção dos sujeitos, consideramos frequentes as crianças que apresentaram presença superior a $60 \%$ dos 200 dias letivos, conforme determinação da Lei no 12.796 (BRASIL, 2013), em seu Art.31, e, neste viés, foram consideradas infrequentes aquelas que apresentaram um número acima de $40 \%$, ou seja, mais de 80 faltas anuais. 
Quadro 2 - Identificação dos entrevistados

\begin{tabular}{|c|c|c|}
\hline Instituição & Entrevistado & Sigla \\
\hline \multirow{5}{*}{ EMEI A } & Familiares & $\begin{array}{l}\text { FA1 - familiar de criança frequente na creche. } \\
\text { FA2 - familiar de criança frequente na pré- } \\
\text { escola. } \\
\text { FA3 - familiar de criança infrequente na } \\
\text { creche } \\
\text { FA4 - familiar de criança infrequente na pré- } \\
\text { escola. }\end{array}$ \\
\hline & Auxiliar de Secretaria & ASA \\
\hline & Coordenadora Pedagógica & $\mathrm{CPA}$ \\
\hline & Professora & $\mathrm{PA}$ \\
\hline & Vice-diretora & VDA \\
\hline \multirow{5}{*}{ EMEI B } & Familiares & $\begin{array}{l}\text { FB1 - familiar de criança frequente na creche. } \\
\text { FB2 - familiar de criança frequente na pré- } \\
\text { escola. } \\
\text { FB3 - familiar de criança infrequente na } \\
\text { creche } \\
\text { FB4 - familiar de criança infrequente na pré- } \\
\text { escola }\end{array}$ \\
\hline & Auxiliar de Secretaria & ASB \\
\hline & Coordenadora Pedagógica & CP-B \\
\hline & Professora & $\mathrm{PB}$ \\
\hline & Vice-diretora & VDB \\
\hline \multirow{5}{*}{ EMEI C } & Familiares & $\begin{array}{l}\text { FC1 - familiar de criança frequente na creche. } \\
\text { FC2 - familiar de criança frequente na pré- } \\
\text { escola. } \\
\text { FC3 - familiar de criança infrequente na } \\
\text { creche } \\
\text { FC4 - familiar de criança infrequente na pré- } \\
\text { escola }\end{array}$ \\
\hline & Auxiliar de Secretaria & ASC \\
\hline & Coordenadora Pedagógica & $\mathrm{CPC}$ \\
\hline & Professora & $\mathrm{PC}$ \\
\hline & Vice-diretora & VDC \\
\hline GECEDI/SMED & $\begin{array}{l}\text { Gerente de Coordenação da } \\
\text { Educação Infantil }\end{array}$ & G1 \\
\hline
\end{tabular}

Fonte: Elaborada pelas autoras deste artigo com base em dados da pesquisa (SILVA, 2018). 
Em primeiro lugar, buscou-se apreender as concepções inerentes à função da instituição pública de Educação Infantil e as expectativas apresentadas por familiares e profissionais quanto às práticas de cuidado e educação realizadas nesses locais. Os depoimentos do grupo de familiares indicam que existe uma concordância com relação ao caráter educativo que as instituições exercem, demonstrando que passaram a exercer junto às famílias a tarefa de partilha não apenas de guarda, mas também de promoção do desenvolvimento das crianças pequenas, conforme Chamboredon e Prévot (1986). As falas a seguir ilustram tal argumento:

$\mathrm{Eu}$ matriculei ela mais porque eu precisava trabalhar, e também porque eu achei que o desenvolvimento dela, ela necessitava. (FA1).

[...] no começo ela foi pra escolinha, ela tinha um ano e sete meses. Quando ela foi pra escolinha, era porque eu estava trabalhando. Depois que eu saí não tinha porque ela sair, aí eu deixei ela, eu preferi deixar, preferi deixar ela na escolinha, só tirei do horário integral, deixei só a parte da tarde. (FC2).

Então, no início foi mais pra conseguir um lugar pra ela ficar mesmo, né?! Depois a gente vai entendendo a importância da Educação Infantil. 0 meu filho não entrou tão cedo quanto ela aqui e ela, assim, todas as etapas dela foi mais avançado que ele. Ela aprendeu cores mais rápido, a coordenação motora foi mais tranquila do que ele, então, no início foi mais um lugar pra ela ficar, depois eu fui vendo a importância que tinha pra vida dela, sabe? (FC1).

Uma importante constatação refere-se ao fato de que os familiares entrevistados desejaram a Educação Infantil para as crianças e as motivações para a procura por uma instituição pública foram diversas, tendo em vista que, além de se justificarem pela possibilidade de ter um local seguro para as crianças ficarem enquanto as mães estivessem no trabalho, também foram citados o auxílio com o sustento da criança e indicação médica. Além disso, os depoimentos das famílias indicam um consenso sobre a relevância da atuação das EMEI para um desenvolvimento satisfatório das crianças em diversos aspectos, mesmo entre o grupo de famílias das crianças consideradas infrequentes, demonstrando que o elevado número de faltas não necessariamente indica uma desvalorização do trabalho realizado pelas instituições.

Eu não tinha dinheiro de Bolsa Família, não tinha dinheiro pra comprar as coisas pra ele em casa e na UMEI eu sabia que ele ia ter uma alimentação melhor do que em casa. (FC3).

Então, quando eu descobri o diagnóstico da patologia do H. [criança], eu fazia acompanhamento no S. [Hospital], e eles sugeriram matricular o H. na escola, aí fizeram uma busca por escolas inclusivas e tal e o S. me orientou a procurar a UMEI pela questão da inclusão. Então esse é o principal motivo. Pra que ele conseguisse desenvolver a questão social. Ainda tem muito a ser desenvolvido, mas já colaborou bastante pra ele, assim, no dia a dia. (FA3).

Ela desenvolveu bastante, ela tem problema na fala... soltou a língua, mudou bastante, tá falando muito fluente agora, era enrolado demais, era muito enrolado, mudou pra melhor, graças a Deus. (FC1).

Acho que a Educação Infantil é muito importante pra criança, pra ela inserir mesmo, tá socializando com outra criança, né, uma fase de aprendizagem e de crescimento pra criança, então eu acho muito importante a educação infantil. (FB2).

As entrevistas permitiram constatar que existe um sentido de valorização da EMEI como espaço educativo e de promoção do desenvolvimento infantil por parte dos familiares.

Quando perguntadas a respeito da frequência escolar, todas as entrevistadas, incluindo as mães dos dois grupos - o grupo das crianças frequentes e o grupo das infrequentes -, foram unânimes ao afirmar que a frequência escolar na Educação Infantil é importante e que, para além de realizar a matrícula, é necessário que as famílias garantam que a criança esteja na instituição todos os dias. Interessante observar que as justificativas para esta presença efetiva foram bastante variadas. Conforme pode ser conferido nos trechos a seguir, perpassam pela concepção a respeito da importância da Educação Infantil para o desenvolvimento integral da 
criança, para a preparação para o ensino fundamental e para a promoção da socialização.

Eu acho que sim, porque é aí que se aprende a tomar gosto. Igual eu, sou formada cedo, formei com dezoito anos, mas é porque meu pai sempre insistiu, tanto eu quanto meus irmãos, de frequentar a escola, desde bem novinha. E não tenho que passar isto pra ela, né? Estes meninos de hoje em dia não tá estudando, tá só indo na escola pra fazer bagunça. Tem que ir pra aprender. Ela desenvolveu bastante, ela tem problema na fala... soltou a língua, mudou bastante, tá falando muito fluente agora, era enrolado demais, era muito enrolado, mudou pra melhor, graças a Deus. (FC1).

Ah, eu acho, não é o meu caso, né, mas eu acho que é a falta de comprometimento dos pais. Talvez alguns pais não acreditem que estar na pré-escola seja tão importante. As pessoas pensam que 'Ah, quando chegar lá no primeiro ano ela se desenvolve', e eu não vejo por este caminho. Eu acho que a pré-escola é extremamente importante para o desenvolvimento como um todo, uma base. (FA3).

Pra não faltar de forma nenhuma eu acho que exige muito do pai e da mãe. Porque se o pai e a mãe fazer isto pra ajudar os filhos, com certeza vai ser muito bom pra criança, porque, realmente, eles não tem nem noção, né? Se o pai e a mãe não fazerem isto, no meu caso é mãe, né? Porque quem fica com eles na verdade, cuida o tempo todo, sou eu. Então eu acho que depende do pai e da mãe. Ali de quem cuida de verdade, né? (FB4).

Ah, eu acho que é pelo desenvolvimento... pra tornar frequente, esta percepção da importância, esta percepção que é importante a educação infantil, vai ajudar na formação, vai ajudar o fundamental também, o desenvolvimento no ensino fundamental, é quando o pai também precisa trabalhar, não tem com quem deixar. (FB1).

A frequência é importante porque ele [a criança] vai pra socializar. Principalmente nos dias de hoje, socializar é importantíssimo. Porque se uma criança hoje fica tão introvertida, eu acho que vai ser um ser humano que vai sofrer muito, principalmente na fase adulta, na adolescência. Hoje a gente vê esta super proteção, as crianças ficam tão ali, naquele mundo delas, que quando ela chega na fase adulta ela se perde e a gente vê este tanto de coisa que acontece. Então eu acho que desde pequeninho ela deve se socializar, aprender a lidar com problema, dividir, aí a parte escolar, que você precisa de uma base pra você começar, então eu acho que tudo isto é importante. Então antigamente... antigamente as mães tinham dez filhos e socializava dentro de casa porque tinha dez filhos, sete filhos. Hoje se tem um, eu tenho uma, então fica no mundinho. Ela tá brincando ali, mas ela brincando com outra criança ela vai ser uma troca e as pessoas precisam desta troca hoje, porque o mundo hoje tá muito digitalizado. Muito! Então as pessoas, se elas ficarem muito sozinhas, vão ser péssimos adultos, na minha concepção. Por isto que eu acho importante socializar desde pequenininho. Principalmente no mundo de hoje, você precisa socializar, você tem que aprender as diferenças. (FA4).

Quanto à concepção dos profissionais a respeito da frequência escolar, foi possível constatar que alguns deles consideram a frequência escolar como concretização do direito à educação e como possibilidade de proteção da criança frente às vulnerabilidades sociais. Nesse ponto, ressaltaremos as opiniões de duas profissionais que atuam na EMEI $C$ e que explicitaram de forma contundente a ideia de frequência escolar como direito da criança, sendo os adultos responsáveis por garantir sua efetivação.

Olha, a presença com certeza é importante, é um momento que ela tem, é a oportunidade que ela tem de frequentar, é um direito, acima de tudo, que ela tem de estar frequentando, estar participando, de estar inserida na educação infantil. E acredito também que, pra nós, é um desafio, porque a gente sabe que a criança não tem um sindicato, não tem quem a defenda e nós somos o porta-voz desta criança, então é importante que elas estejam aqui até mesmo pra gente saber o que tá acontecendo do outro lado. Porque a ponte que tem pra gente saber o que acontece com as famílias é a criança. Então pra mim é fundamental, é essencial a presença dela, sim, na escola. (CPC).

Com certeza, pois a criança não é o foco do trabalho com a educação infantil?! Então a gente acredita que a criança, ela precisa ter uma boa frequência na educação infantil para desenvolvimento do trabalho. Se a gente pensa nos projetos, se a gente pensa no desenvolvimento 
integral da criança, e tendo ela como foco, a primeira coisa que a gente precisa pensar é a questão da frequência. Imagina? Se a gente começa um trabalho e a gente não tem uma boa frequência dos alunos, o trabalho não vai ser bem desenvolvido. (VDC).

Os depoimentos anteriores referem-se às profissionais que trabalham na EMEI $\mathrm{C}$, a que atende a população mais vulnerável dentre as três pesquisadas e que, durante a análise dos diários de classe, foi a que apresentou o maior número de faltas ao final do ano de 2016. As profissionais demonstram ter consciência da importância do atendimento para a população local e, apesar de ressaltarem a responsabilidade familiar para que a criança tenha uma frequência escolar satisfatória, apresentaram a percepção de que as condições sociais e econômicas das famílias podem também influenciar para que os índices de frequência sejam mais baixos que nas demais EMEI. Esse aspecto fica evidente no seguinte trecho proferido pela vice-diretora:

Por que a gente que é mãe, a gente sabe a rotina, a organização pessoal que a gente tem que ter pra mandar o menino pra escola todos os dias às 7 horas da manhã. Imagine pra uma família sofrida? Imagina pra uma família que não tem banheiro dentro de casa, que não tem as coisas direito dentro de casa, né, que não tem roupa às vezes direito, dependendo da estação do ano... às vezes não tem roupa limpa, a gente tem casos aqui! Como que você organiza a sua vida pra você todo dia ter aquela rotina de mandar a criança pra escola? Pra gente já é difícil, né? Com toda estrutura que a gente tem em casa, boa estrutura familiar... e eu não falo só de uma família típica, mas eu falo de relações mesmo funcionais dentro de casa. Pra gente já é difícil todo dia manter uma rotina desta! Então, todo dia sair às 13 horas e dar conta de fazer almoço e dar almoço pras crianças, às vezes não tem fogão, às vezes não tem gás... você imagina organizar sua rotina pra que todos os dias naquele horário a criança esteja no horário. Então, é lógico que a gente não manda criança nenhuma voltar pra casa, mas intima uma criança que está chegando todos os dias 8h30, 9 horas... Mas você faz uma 'pressãozinha', você manda um livro de ocorrência, você cria um mecanismo pra família entender que aquela rotina na escola é importante, então, eles podem chegar... Igual o caso dessa mãe adolescente que eu citei aí. Às vezes chegar $8 \mathrm{~h} 30,9 \mathrm{~h}$, 'Ah, eu não dei conta de acordar.," e aí? Não tem um adulto responsável, o adulto não mora na casa, a irmã mais velha está presa, então... você conversa, você explica: 'Você precisa colocar o celular pra despertar, você precisa pôr esta criança pra dormir mais cedo.' Você explica de todo jeito, mas... às vezes ela chega aqui: 'Já sei o que você vai falar!'. Mas nem sempre se muda a realidade desta família, deste cuidador, desta criança. (VDC).

A professora (PC) que atua nessa mesma instituição também revelou preocupação com a situação social das crianças atendidas e entende a frequência escolar como forma de garantir meios para proteger aquelas mais vulneráveis, ressaltando o direito de estarem na EMEI:

Eu acho que é direito da criança, né? [a frequência escolar] eu prezo... Ainda mais o J, nosso aluno, ele precisa muito estar aqui e é bom ele estar aqui, tem criança que é mais segura na escola do que na família, né? Eu acredito assim, não é o ideal, né? A família tem que ser o abrigo mesmo, o suporte, a base, o refúgio, mas tem crianças que estão mais bem cuidadas aqui. (PC).

Essa assertiva coincide com o argumento apresentado por Monteiro (2003) a respeito da relevância das medidas estatais para garantir a promoção e a proteção do direito à educação, especialmente nos casos em que as famílias são mais vulneráveis. De acordo com ele, o Estado é o principal responsável pela efetivação do direito à educação, em primeiro lugar porque as famílias pobres não têm condições de efetivar meios para alcançá-lo, e em segundo lugar porque o Estado deve garantir o "Bem Comum". Nesse sentido, ele complementa que "A metade das crianças do mundo cuja satisfação do direito à educação é prejudicada por obstáculos financeiros e as crianças de mais de 40 Estados onde a escola primária ainda não é obrigatória nem gratuita, só podem ter esperança na responsabilidade do Estado" (MONTEIRO, 2003, p. 770).

Os depoimentos dos familiares ao apresentarem as justificativas para a infrequência escolar são relevantes nessa análise ao oferecerem 
subsídios para afirmarmos que a garantia do direito à Educação Infantil ultrapassa a mera disposição da vaga, pois esbarra em situações cotidianas que ameaçam a permanência da criança na instituição, especialmente para as famílias mais vulneráveis.

0 adoecimento infantil foi citado de forma recorrente pelas famílias das três instituições como principal motivo de falta das crianças, confirmando os dados encontrados durante a aplicação dos questionários. Entretanto, para as famílias da EMEI C, a qual está localizada na área mais vulnerável da Região Norte, tal condição é potencializada por fatores que incluem dificuldade de acesso em dias chuvosos, doenças causadas pelas condições das moradias e pelo aumento da poeira causada pela falta de pavimentação das ruas. Tais fatores apareceram de forma mais frequente nos depoimentos dessas famílias que residem na área de ocupação urbana e que são atendidas pela instituição, conforme os exemplos a seguir:

Quando ela tá doentinha. Ou então, se tiver chovendo muito, muito, muito mesmo, porque é longe pra vir, né? Eu não moro tão longe, mas é um morro, tem rua de terra, aí eu prefiro não. Mas a chuva tem que tá bem forte mesmo, mas quando não, ela tem que vir pra escola. (FC1).

Só por causa de doença, porque ela tem bronquite. Inverno e período de chuva. E ela tem muito problema, além da bronquite ela tem muita otite. Então, direto eu tenho que buscar ela e ela fica alguns dias sem vir. (FA1).

E, às vezes, quando tá chovendo bastante também de manhã, porque é muito barro, aí escorrega bastante pra vir pra cá. [...] eu fico com muita dó dele, de mandar ele debaixo de chuva. É... eu já caí com ele, trazendo ele pra escola, ele tinha um ano e eu caí com ele no barro. (FC3).

Onde a gente mora é rua de terra. Quando chove, é muito difícil descer. (FC4).

O grupo de profissionais da educação indicou de forma recorrente que a infrequência escolar na Educação Infantil está relacionada à falta de valorização do trabalho educativo desenvolvido nas instituições, conforme indicam os depoimentos a seguir:
Outra questão que eu acho, assim, eu vejo muito na experiência diária aqui é que os pais realmente, a princípio, não têm muito esta consciência da frequência da criança, por ser criança, não tem notas, provas, avaliações, vamos dizer assim. Talvez os pais não dão tanta importância à frequência, mas no nosso caso aqui, na nossa UMEI, a frequência não é baixa não, ela é bastante razoável. (ASA),

E fora isto, tem aqueles casos mesmo de famílias que: 'Ah, não vou mandar porque tá chovendo, porque tá frio, ah, não tem problema faltar.' Tem estas questões também. (VDA).

Da família, com certeza, a grande maioria. Uma vez ou outra fala que a criança que não quis vir, mas na maioria das vezes é 'não deu pra eu trazer', 'não tinha ninguém'. A maioria. Eu tenho uma aluna que eu perguntei: 'Por que você não veio?' 'Ah, não consegui acordar.' Uma semana de faltas porque não conseguiu acordar?! (PB).

Principalmente no turno da manhã, qualquer coisa é motivo pra criança não vir pra aula, além das doenças que acontecem mesmo nesta fase, né?! Mas muitos não vêm porque, ah, por qualquer outro motivo. No turno da manhã. No turno da tarde é mais frequente. (CPB).

É... O turno da manhã tem uma infrequência maior porque às vezes os pais não acordam, ou tá chovendo, tá fazendo frio, então eles acabam não trazendo, ou então a mãe tá de folga, não vem, o pai tá de folga. Então a infrequência da manhã é maior, da tarde não. E a gente percebe uma infrequência maior também das crianças do parcial. As crianças do integral, que geralmente a mãe deixa aqui pra ir trabalhar, elas faltam menos, mas as do parcial costumam ter uma frequência menor, parece que os pais acham que não tem importância a criança faltar. Temos muitas famílias que são preocupadas com esta frequência e elas ligam na escola, elas justificam, às vezes até trazem a criança doente com medo de perder a vaga, aí a gente explica como que funciona, que tem que justificar, trazer um atestado médico... mas tem alguns também que fingem que tão nem aí. (VDB).

Diante de tais depoimentos é necessário salientar que entre as familiares entrevistadas não houve menção à falta de valorização da EMEI como justificativa para as faltas, tendo em vista que, como já foi citado neste artigo, 
houve um consenso quanto ao reconhecimento da importância do trabalho realizado pelas instituições em favor do desenvolvimento infantil, mesmo nos casos em que a motivação da matrícula tenha sido a necessidade de guarda e assistência ou, ainda, naqueles em que existem outros impedimentos para uma frequência escolar efetiva.

Para a profissional que atua na GECEDI, os motivos das faltas podem ser resultado de condições sociais distintas que influenciam a organização da rotina diária das crianças e de suas famílias. Tal constatação é baseada em sua experiência no acompanhamento da organização do atendimento às crianças no município e indica que muitas das causas de infrequência estão ligadas à situação de vulnerabilidade em que se encontram um número significativo de famílias atendidas.

A gente tem, por exemplo, problema de gangue, de facção, em aglomerados. Então tem época que um aglomerado está em guerra com o outro, e a família não pode transitar de um aglomerado pro outro. $E$ a gente tem que entender também que, por exemplo, a matrícula é compulsória pra crianças sob medida de proteção. 0 que é medida de proteção na nossa política? Criança abusada sexualmente. Muitas vezes o abusador está em casa, né. Então, ele vai querer que a criança esteja na EMEI? Tudo isto é muito cuidado, se tem suspeita, se tem alguma coisa, que evidencie alguma questão relacionada a isto, imediatamente a gente faz ficha de notificação, manda pro Conselho, mas a gente tem esse problema na rede. Criança explorada na mendicância, criança explorada no trabalho infantil, então, quer dizer, é questão de sustento, né? Já teve uma UMEI em que a menina não tinha sapato, ela estava indo sem sapato e estava fazendo muito frio. Aí a diretora da UMEI falou com a mãe da menina: 'Olha, tá fazendo muito frio, ela tá vindo sem sapato, sem meinha.' Aí a mãe falou: 'Vamo fazer o seguinte: hoje eu vou pro sinal e vou comprar um sapato pra ela, vou com ela pro sinal pra ter dinheiro, pra ter dinheiro pra comprar um sapato pra ela.' Então, esses meninos, muitas vezes, eles significam recursos, dinheiro, né? Criança filho de mulher que sofreu violência doméstica... Então às vezes a situação de violência na família é tão caótica que fica difícil até a mãe sair. Às vezes por agressão, né? Medo de se expor, medo mesmo de encontrar com o agressor no meio do caminho. Tem também criança filho de adolescente que cumpre medida socioeducativa. Então, você pensa bem: $\mathrm{o}$ adolescente está cumprindo medida seja por algum ato infracional, agora imagina a responsabilidade dele com o filho, né? Muitas vezes é a avó, já de idade, que cuida; criança abrigada... Estas medidas de proteção, a gente sempre fala: 'Pra nós é o CTI da infância.' Criança que corre risco de morte. Corre risco de morte por quê? Muitas vezes pela própria condição familiar, né? E o adoecimento é muito grande, fragilidade, às vezes tem menino muito desnutrido. A gente vê menino, assim, que chega muito desnutrido na UMEI e que com pouco tempo ele consegue uma saúde razoável, mais estável, mas é assim, segunda ele chega péssimo, aí ao longo da semana ele vai se recuperando, aí ele vai pro final de semana, volta segunda de novo muito, com muita chieira, muita bronquite, então ainda tem esta questão do adoecimento na educação infantil. A criança pequena tem esta questão destas doenças que são comuns na infância. (G1).

Interessante observar que alguns desses fatores foram citados por profissionais que trabalham na EMEI C, demonstrando o reconhecimento da situação de vulnerabilidade das famílias locais. De acordo com a professora (PC), por exemplo, os problemas podem afetar até mesmo as crianças que demonstram gostar do ambiente institucional.

Assim, há infrequência, há uma grande infrequência. Mas nos outros anos. 0 ano passado eu estava com a turminha de quatro anos, eu achei que meus alunos eram bem frequentes. Eles gostam muito de ir pra escola, pelo menos meus alunos do ano passado, mas a infrequência aqui perpassa muito por isto, pela questão da saúde, pela questão... às vezes, quando chove muito, muitos moram na invasão, às vezes a dificuldade de sair de casa, porque onde mora é lugar... barranco, né? Tem muito barro. Tem pais que não tiram a criança de casa, tem outros que enfrentam mesmo as circunstâncias e vai. (PC).

Em contrapartida, a vice-diretora da EMEI A (VDA) demonstrou que tais situações não são determinantes para a realidade local desta instituição: 
Olha, aqui na UMEI $\mathrm{A}$, a gente não tem outras [outras causas além do adoecimento], porque poderia pensar numa questão geográfica, né, no sentido da moradia, mas não é o nosso caso aqui não. É igual eu falei pra você, quando chove é porque não quer mesmo tirar da cama, né?! Porque não tem aquela questão, assim, de alagamento, porque a criança não vem por uma questão mesmo do clima. Mas agora, no turno da manhã, eles são menos frequentes, justamente por esta questão de ter que tirar da cama pra trazer pra escola, né?! E aí a gente tem muitos atrasos e chegam $7 \mathrm{~h} 30$. E os atrasos também a gente procura registrar, até pra trazer mesmo esta consciência deles. (VDA).

O contraponto entre os depoimentos dessas profissionais reforça a constatação de que, apesar de existir uma proximidade territorial entre as três EMEI pesquisadas, elas apresentam perfis bem distintos de público atendido, confirmando os dados encontrados durante a análise dos questionários. Confirmam também que as famílias mais carentes, mesmo aquelas moradoras da área urbana, enfrentam não somente dificuldades de acesso, mas também de permanência nas instituições de ensino.

\section{Considerações finais}

Os resultados apresentados neste trabalho indicaram que o acompanhamento da frequência escolar não pode ser percebido como mero registro burocrático e mecânico de presenças e ausências das crianças nas creches e pré-escolas. Ainda que consideremos as limitações e o caráter provisório que toda investigação possui, uma conclusão inevitável é a de que existe uma pergunta que deve ser feita diariamente pela instituição educacional: "Por que as crianças deixam de vir para a creche ou pré-escola?"

Conforme foi verificado, as respostas não são únicas e simples. Não podem ser analisadas sem considerar recortes sociais. Isso se confirma pela constatação de que as três EMEIs pesquisadas possuem proximidade em relação à localização geográfica, mas apresen- tam disparidades consideráveis em relação às variáveis, como renda, escolaridade, cor, moradia, configurações familiares e gênero, 0 que acaba reverberando em índices distintos de frequência escolar. Os dados mostraram indicadores mais elevados de vulnerabilidade social entre as crianças atendidas pela EMEI C, que se situa próxima a território de moradia por ocupação. Nessa situação de vulnerabilidade social é que foi encontrado um elevado índice de infrequência, conforme dados dos diários de classe.

Outro resultado interessante consiste no contraponto encontrado entre os depoimentos de familiares e profissionais a respeito dos motivos de falta das crianças, tendo em vista que os profissionais inferiram que uma das principais causas da infrequência seria a desvalorização por parte das famílias do trabalho educativo realizado pelas EMEI. Contudo, durante as entrevistas, as famílias demonstraram reconhecer a contribuição das atividades realizadas diariamente nas instituições para um desenvolvimento infantil satisfatório. Em outras palavras, os depoimentos dos familiares indicam que um elevado número de faltas não significa, necessariamente, a desvalorização do trabalho realizado nas instituições. As ausências estão mais relacionadas a uma variedade de causas, associadas ao adoecimento, às dificuldades de acessibilidade pelas condições urbanas de mobilidade e moradia e às formas de organização familiar.

As conclusões da pesquisa apontaram, portanto, para a existência de situações diversas que envolvem a vida das crianças e de suas famílias e que afetam diretamente os índices de frequência escolar. Além do adoecimento infantil, o principal motivo para as faltas, assinala-se a existência de condições que podem influenciar nos índices de frequência escolar das crianças, os quais demonstram ter relação com variáveis referentes à situação econômica e social das famílias, tais como a escolaridade dos responsáveis, o local de moradia e as configurações familiares 
Cumpre registrar o desejo de que os resultados desta investigação possam suscitar o desenvolvimento de outras pesquisas que tenham a frequência escolar como temática. Espera-se também que os sistemas de ensino criem meios para um acompanhamento e monitoramento das faltas das crianças, motivados pelo reconhecimento de que a frequência escolar efetiva pode funcionar como indicador da concretização do direito de acesso e permanência na Educação Infantil, conforme foi defendido por algumas das profissionais que participaram da pesquisa.

\section{REFERÊNCIAS}

AMORIM, Katia S.; ROSSETTI-FERREIRA, Maria Clotilde. Creches com qualidade para a educação e o desenvolvimento integral da criança pequena. Psicologia, Ciência e Profissão, v. 19, n. 2, p. 6469, 1999.

BABIUK, Graciele Alves. Famílias monoparentais femininas, políticas públicas em gênero e raça e serviço social. SEMINÁRIO NACIONAL DE SERVIÇO SOCIAL, TRABALHO E POLÍTICA SOCIAL, 1., 2015, Florianópolis. Anais eletrônicos [...]. Florianópolis: Universidade Federal de Santa Catarina, 2015. Disponível em: https://repositorio.ufsc.br/xmlui/ handle/123456789/180860. Acesso em: 01 maio 2018.

\section{BELO HORIZONTE. Histórias de bairros [de] Belo}

Horizonte: Regional Norte/coordenador, Raphael Rajão Ribeiro. Belo Horizonte: Arquivo Público da Cidade, 2011.

BIZZOTTO, Luciana Maciel. \#RESISTEIZIDORA: controvérsias do movimento de resistência das Ocupações da Izidora e apontamentos para a justiça urbana. 180 f. Dissertação (Mestrado em Arquitetura) - Escola de Arquitetura, Universidade Federal de Minas Gerais (UFMG), Belo Horizonte, 2015.

BRASIL. Presidência da República. Casa Civil. Constituição da República Federativa do Brasil. Brasília, DF, 1988. Disponível em: http:// www.planalto.gov.br/ccivil_03/constituicao/ constituicao.htm. Acesso em: 29 mar. 2017.

BRASIL. Presidência da República. Casa Civil. Lei n. 9.394, de 20 de dezembro de 1996. Dispõe sobre as Diretrizes e Bases da Educação Nacional.
Brasília, DF, 1996. Disponível em: https://www2. camara.leg.br/legin/fed/lei/1996/lei-9394-20dezembro-1996-362578-publicacaooriginal-1-pl. html. Acesso em: 29 mar. 2017.

BRASIL. Presidência da República. Casa Civil. Lei n. 12.796, de 04 de abril de 2013. Altera a Lei n. 9.394, de 20 de dezembro de 1996, que estabelece as diretrizes e bases da educação nacional, para dispor sobre a formação dos profissionais da educação e dar outras providências. Brasília, DF, 2013. Disponível em: http://www.planalto.gov.br/ ccivil_03/_ato2011-2014/2013/lei/L12796.htm. Acesso em: 29 mar. 2017.

CAMPOS, Maria Malta. A Educação Infantil como direito. In: CAMPANHA NACIONAL PELO DIREITO À EDUCAÇÃO. Insumos para o debate 2 - Emenda Constitucional n. 59/2009 e a educação infantil: impactos e perspectivas. São Paulo: Campanha Nacional pelo Direito à Educação/Instituto C\&A, 2010. p. 8-13.

CHAMBOREDON, Jean-Claude; PRÉVOT, Jean. 0 ofício de criança: definição social da primeira infância e funções diferenciadas da escola maternal. Cadernos de Pesquisa, São Paulo, n. 59, p. 32-59, nov. 1986.

DIDONET, Vital. Nota de esclarecimento sobre a PEC 277/2008. 2009. Disponível em: http:// www.omepms.org.br/web/site/misc_print_txt. php? chn=3\&txt=1246394940. Acesso em: 05 fev. 2018.

GIL, Antônio C. Métodos e técnicas de pesquisa social. 6. ed. São Paulo: Atlas, 2008.

GOMES. Nilma Lino. Diversidade étnico-racial, inclusão e equidade na educação brasileira: desafios, políticas e práticas. Revista Brasileira de Política e Administração da Educação, v. 27, n. 1, p. 109-121, jan./abr. 2011.

INSTITUTO BRASILEIRO DE GEOGRAFIA E ESTATÍSTICA (IBGE). Censo demográfico 2010. Família e domicílio. Rio de Janeiro, 2012. Disponível em: http://www.ibge.gov.br/home/presidencia/ noticias/imprensa/ppts/00000010435610212 012563616217748.pdf. Acesso em: 07 jul. 2017.

INSTITUTO BRASILEIRO DE GEOGRAFIA E ESTATÍSTICA (IBGE). Pesquisa Nacional por Amostra de Domicílios Contínua 2016. Rio de Janeiro, 2017. Disponível em: http://www.ibge.gov. br. Acesso em: 03 mar. 2019.

INSTITUTO BRASILEIRO DE GEOGRAFIA E ESTATÍSTICA (IBGE). Pesquisa Nacional por 
Amostra de Domicílios Contínua 2018. Rio de Janeiro, 2019. Disponível em: http://www.ibge.gov. br. Acesso em: 03 mar. 2019.

MARANHÃO, Damaris Gomes; SARTI, Cynthia Andersen. Creche e família: uma parceria necessária. Cadernos de Pesquisa, São Paulo, v. 38, n. 133, p. 171-194, abr. 2008. Disponível em: http://www.scielo.br/scielo.php?script=sci_ arttext\&pid=S0100-15742008000100008\&lng=e n\&nrm=iso. Acesso em: 08 jun. 2018.

MONTEIRO, Agostinho dos Reis. 0 pão do direito à Educação. Educação \& Sociedade, Campinas, SP, v. 24, n. 84, p. 763-789, set. 2003.

MOTTA, Eduardo Marcheti Pereira Leão da. Medindo a desigualdade socioespacial: os aglomerados subnormais em Belo Horizonte. In: ENCONTRO NACIONAL DA ASSOCIAÇÃO NACIONAL DE PÓSGRADUAÇÃO E PESQUISA EM PLANEJAMENTO URBANO E REGIONAL (ANPUR), 17., 2017, São Paulo. Anais eletrônicos [...]. São Paulo: ANPUR, 2017. Disponível em: http://anais.anpur.org.br/ index.php/anaisenanpur/article/view/2376. Acesso em: 01 ago. 2019.

PEDRAZA, Dixis Figueroa; QUEIROZ, Daiane de; SALES, Márcia Cristina. Doenças infecciosas em crianças pré-escolares brasileiras assistidas em creches. Ciência e Saúde Coletiva, Rio de Janeiro, v. 19, n. 2, p. 511-528, fev. 2014. Disponível em: http://www.scielo.br/scielo.php? script=sci arttext\&pid=S1413-81232014000200511\&lng=e n\&nrm=iso. Acesso: 01 maio 2018.

PROGRAMA DAS NAÇÕES UNIDAS PARA O DESENVOLVIMENTO (PNUD). Índice de Desenvolvimento Humano Municipal Brasileiro. Brasília, DF: PNUD/Ipea/FJP, 2013. Disponível em: https://www.ipea.gov.br/portal/images/stories/ PDFs/130729_AtlasPNUD_2013.pdf. Acesso em: 07 jul. 2017.

RAPOPORT, Andrea; PICCININI, Cesar Augusto. 0 ingresso e adaptação de bebês e crianças pequenas à creche: alguns aspectos críticos. Psicologia: Reflexão e Crítica, Porto Alegre, v. 14, n. 1, p. 81-95, 2001. Disponível em: http://www.scielo. br/scielo.php?script=sci_arttext\&pid=S010279722001000100007\&lng=en\&nrm=iso. Acesso em: 01 maio 2018.

SILVA, Maria Beatriz de Oliveira Vasconcelos. "Ele precisa muito estar aqui, é bom ele estar aqui!": frequência escolar na Educação Infantil. 2018. 160 f. Dissertação (Mestrado em Educação) - Faculdade de Educação, Universidade Federal de Minas Gerais (UFMG), Belo Horizonte, 2018.

SZYMANSKI, Heloisa. Entrevista reflexiva: um olhar psicológico sobre a entrevista em pesquisa. In: SZYMANSKI, Heloisa (org.). A entrevista na pesquisa em educação: a prática reflexiva. Brasília, DF: Plano, 2002. p. 9-64.

VIEIRA, Lívia M. F. Obrigatoriedade escolar na educação infantil. Revista Retratos da Escola, Brasília, DF, v. 5. n. 9, p. 245-262, jul./dez. 2011.

XIMENES, Daniel de Aquino. Vulnerabilidade social. In: OLIVEIRA, D. A.; DUARTE, A. M. C.; VIEIRA, L. M. F. Dicionário de verbetes: trabalho, profissão e condição docente. Belo Horizonte: UFMG/ Faculdade de Educação, 2010. Disponível em: http://gestrado.net.br/index.php?pg=dicionarioverbetes\&id=235. Acesso: 30 out. 2017.

Recebido em: 10/03/2020 Aprovado em: 12/12/2020

(cc) BY-No Este é um artigo publicado em acesso aberto sob uma licença Creative Commons. 